\title{
Dipirona: ¿Beneficios subestimados o riesgos sobredimensionados? Revisión de la literatura
}

Tatiana Patricia Buitrago-González¹, Carlos Alberto Calderón-Ospina², Álvaro Vallejos-Narváez³

1,2 Escuela de Medicina y Ciencias de la Salud. Universidad del Rosario. Carrera 24 No. 63C-69. Bogotá, D. C., Colombia.

${ }^{3}$ Facultad de Medicina, Fundación Universitaria de Ciencias de la Salud. Carrera 19 No. 8A-32. Bogotá, D. C., Colombia.

${ }^{1}$ Correo electrónico: buitrago.tatiana@urosario.edu.co.

${ }^{2}$ Correo electrónico: carlos.calderon@urosario.edu.co.

${ }_{3}^{3}$ Correo electrónico:agvallejos@gmail.com.

Recibido para evaluación: 12 de diciembre de 2013.

Aceptado para publicación: 29 de mayo de 2014.

\section{RESUMEN}

La dipirona es un analgésico, antipirético, espasmolítico y antiinflamatorio de amplio uso en Colombia y Latinoamérica, proscrito por agencias regulatorias de referencia, por el riesgo de agranulocitosis y otras discrasias sanguíneas. Estos antecedentes han generado controversia e incluso aprensión dentro de los prescriptores, lo cual justifica esta revisión. Una vez revisada la literatura se encuentra que la dipirona es eficaz como antipirético y para el manejo del dolor agudo, crónico, posoperatorio, cólico renal y migraña. La prevalencia de agranulocitosis es de 0,03 al $0,5 \%$ en pacientes europeos y la incidencia de pacientes hispanos está alrededor de 0,38 casos por un millón de habitantes/año y aún menor en anemia aplásica. El riesgo de lesión gástrica es menor que el de otros AINE (antiinflamatorios no esteroideos) de uso habitual y es un medicamento relativamente seguro en el embarazo. Otros efectos adversos incluyen hipersensibilidad, anafilaxia, pénfigo e hipotensión arterial relacionada con la administración intravenosa rápida del medicamento. Conclusiones: la dipirona conlleva un riesgo muy bajo de generar discrasias sanguíneas en población latinoamericana posiblemente por factores farmacogenéticos aún no identificados. Los principales factores de riesgo incluyen la duración del tratamiento, la dosis empleada y el uso concomitante de otros medicamentos que generen mielotoxicidad. 
Palabras clave: dipirona, agranulocitosis, anemia aplásica, farmacovigilancia, toxicidad por medicamentos, resultados del tratamiento.

\title{
SUMMARY
}

\section{Dipyrone: Benefits underestimated or oversized risks? Review of the literature}

\begin{abstract}
Dipyrone is an analgesic, antipyretic, antispasmodic and anti-inflammatory widely used in Colombia and Latin America, outlawed by reference regulatory agencies due to the risk of agranulocytosis and other blood dyscrasias. These facts have generated controversy and even apprehension within prescribers, which justifies this review. After reviewing the literature is that dipyrone is effective as antipyretic and management of acute pain, chronic, postoperative, renal colic and migraine. The prevalence of agranulocytosis is 0.03 to $0.5 \%$ in European patients and the incidence in Hispanic patients is about 0.38 cases per million inhabitants/year and even lower for aplastic anemia. Gastric injury risk is lower than that of other commonly used NSAIDs and is a relatively safe drug during pregnancy. Other adverse effects include hypersensitivity, anaphylaxis, pemphigus and hypotension related to rapid intravenous administration of the drug. Conclusions: Dipyrone carries a very low risk of blood dyscrasias in Latin American population, possibly due to pharmacogenetic factors not yet identified. The main risk factors include duration of treatment, the dose used and the concomitant use of other drugs that produce myelotoxicity.
\end{abstract}

Key words: dipyrone, agranulocytosis, aplastic anemia, pharmacovigilance, drug toxicity, treatment outcome.

\section{INTRODUCCIÓN}

La dipirona es una pirazolona también llamada metamizol, es un fármaco analgésico, antipirético, espasmolítico y con mínimo efecto antiinflamatorio, ampliamente utilizado [1-3]. En 1884, Ludwig Knorr descubrió las pirazolonas, y luego introducidas en el mercado a finales del siglo XIX y ampliamente utilizadas hasta 1970, momento en el cual fueron relacionadas con algunas reacciones adversas como la agranulocitosis [4, 5]. Este medicamento se fabricó por primera vez en Alemania en 1922 y la FDA (Food and Drug Administration), agencia regulatoria de medicamentos estadounidense, prohibió su uso en 1977 [4]. Ha sido censurada en algunos países a causa de una posible asociación con agranulocitosis y anemia aplásica; pero aun así, se sigue utilizando en 